\title{
The antibacterial activity of indium oxide thin film prepared by thermal deposition
}

\author{
Odai N. Salman \\ Applied Physics Branch, Applied Sciences Department, University of Technology \\ E-mail: micro_ud@yahoo.com
}

\begin{abstract}
Indium oxide $\operatorname{In}_{2} \mathrm{O}_{3}$ thin films fabricated using thermal evaporation of indium metal in vacuum on a glass substrate at $25^{\circ} \mathrm{C}$ using array mask, after deposition the indium films have been subjected to thermal oxidation at temperature $400{ }^{\circ} \mathrm{C}$ for $1 \mathrm{~h}$. The results of prepared Indium oxide reveal the oxidation method as a strong effect on the morphology and optical properties of the samples as fabricated. The band gap $(\mathrm{Eg})$ of $\mathrm{In}_{2} \mathrm{O}_{3}$ films at $400{ }^{\circ} \mathrm{C}$ is $2.7 \mathrm{eV}$. Then, SEM and XRD measurements are also used to investigate the morphology and structure of the indium oxide $\operatorname{In}_{2} \mathrm{O}_{3}$ thin films. The antimicrobial activity of indium oxide $\operatorname{In}_{2} \mathrm{O}_{3}$ thin films was assessed against gram-negative bacterium using inhibition zone of bacteria which improved higher inactivation rate observed for gram-negative bacteria and reduced resistance of membrane due to reactive oxygen species generated by thermal oxidation.
\end{abstract}

Key words

Antimicrobial activity of Indium oxide $\mathrm{In}_{2} \mathrm{O}_{3}$, gram negative and gram positive microorganism.

Article info.

Received: Sep. 2017

Accepted: Nov. 2017

Published: Jun. 2018

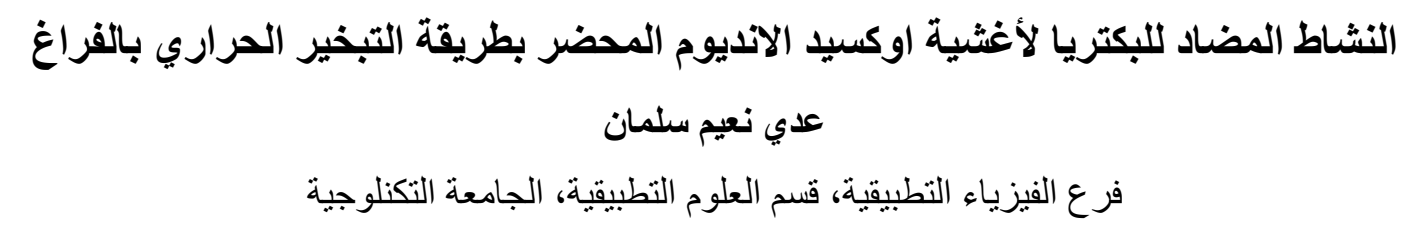

\section{Introduction}

In recent years, preparation and characterization of collection semiconductor materials in nanometer size has been a quickly increasing area of research, because of their excellent chemical and physical properties that are different from those of either bulk material or single atom [1]. Indium oxide $\left(\operatorname{In}_{2} \mathrm{O}_{3}\right)$, a n-type semiconductor material, has a direct band gap of 3.8 $\mathrm{eV}$ and an indirect band gap of $2.8 \mathrm{eV}$ [2]. Its absorption spectrum can extend from ultraviolet region to the visible 
region. It has been widely used in solar cells, flat panel display, and other environmental pollutants [3]. Moreover, there is also $\operatorname{In}_{2} \mathrm{O}_{3}$ nanostructures with various morphologies have been increase and reveal novel shape dependent features, such as improving optical properties and exceptional gas sensing characteristics. However, it is still a new filed to produce new $\operatorname{In}_{2} \mathrm{O}_{3}$ nanostructures with various morphologies in order to develop its features [4]. However, due to the high electron-hole recombination rate, the efficiency of $\mathrm{In}_{2} \mathrm{O}_{3}$ is still limited. In order to improve the photocatalytic effect of $\operatorname{In}_{2} \mathrm{O}_{3}$, researchers have used a variety of techniques, such as morphology control, metal deposition, and combining with semiconductors [3].

Besides, n-type semiconductor material not only has unique optical and optoelectrical characterization but it also has catalytic properties that make the compound suitable for using in the photo-degradation of toxic organic compounds, dyes, pigments and other environmental pollutants due to the enhanced photocatalytic activity that was attributed to the high separation and migration efficiency of photo-induced electrons and holes [4, 5]. Different procedures of formation have been propose, include Chemical Vapor Deposition sputter, evaporation method, thermal oxidation, spray process, etc. [6]. In this work, we determined the morphological and optical properties of array Indium thin film using traditional thermal evaporation method followed with oxidation at temperature $400^{\circ} \mathrm{C}$ for $1 \mathrm{~h}$. Besides, Investigation of antibacterial effect of $\operatorname{In}_{2} \mathrm{O}_{3}$ array thin film in killing of gram-negative bacteria by inhibition zone test and improve the bacteria growth rate is declined by the $\operatorname{In}_{2} \mathrm{O}_{3}$ thin film.

\section{Experimental details}

Indium thin films are deposited using thermal evaporation method. In this method, the indium metallic layers $(99.98 \%)$ are deposited by vacuum thermal evaporation with mask array. The evaporation method was carried out in a conventional vacuum coating under a vacuum of order of $6 \times 10^{-5}$ torr with controlled deposition rate by using pure indium, the distance of about $20 \mathrm{~cm}$ was kept constant between Molybeduim boat and substrate. The indium thin films of thicknesses $350 \mathrm{~nm}$ were grown on glass substrate. The deposition conditions are shown in Table 1 . Then Indium thin layer was achieved in 1hour at $400^{\circ} \mathrm{C}$ in dry air atmosphere by using electric furnace.

The crystalline structure and the Grain size present in the films are determined by XRD analysis. The surface morphology of grown structures was also investigated by Scanning Electron Microscopy (SEM). The absorbance, transmittance and optical energy band gap of the deposited thin film was measured using UV-Vis Spectrophotometer in the wavelength region of 200 to 1100 $\mathrm{nm}$. Besides, the antimicrobial activity of Indium oxide $\mathrm{In}_{2} \mathrm{O}_{3}$ thin films was assessed against gram-negative bacterium to improve their resistance to growth of bacteria in environmental pollutants.

Table 1: Parameters for fabrication of $\mathrm{In}_{2} \mathrm{O}_{3}$ thin films.

\begin{tabular}{|c|c|}
\hline Materials & Pure Indium \\
\hline Substrates & Glass slides \\
\hline Vacuum & $6 \times 10^{-5}$ torr \\
\hline Substrate to film gap & $20 \mathrm{~cm}$ \\
\hline
\end{tabular}

\section{Antibacterial activity of $\operatorname{In}_{2} \mathrm{O}_{3}$ thin films}

Antibacterial activity of $\operatorname{In}_{2} \mathrm{O}_{3}$ thin films against a Gram negative bacterium Escherichia coli (E.coli) 
was investigated by inhibition zone of bacteria. Gram negative bacterium were cultured in an LB medium at 37 ${ }^{\circ} \mathrm{C}$ for $24 \mathrm{~h}$. Bacteria culture was dilution approximately corresponding to MacFarland standard $10^{7} \mathrm{CFU} / \mathrm{ml}$. (10 $\left.{ }^{7} \mathrm{CFU} / \mathrm{ml}\right) .100 \mu \mathrm{l}$ of growing target culture was pour onto the agar plate, allowed to solidify. Then, $\operatorname{In}_{2} \mathrm{O}_{3}$ samples thin films are allowed to diffuse into the agar followed by incubating the plates at $37^{\circ} \mathrm{C}$ for overnight. Upon incubation the zone of clearance around the samples are measured and evaluated.

\section{Results and discussions Optical properties}

The optical properties are studied for the indium oxide films by

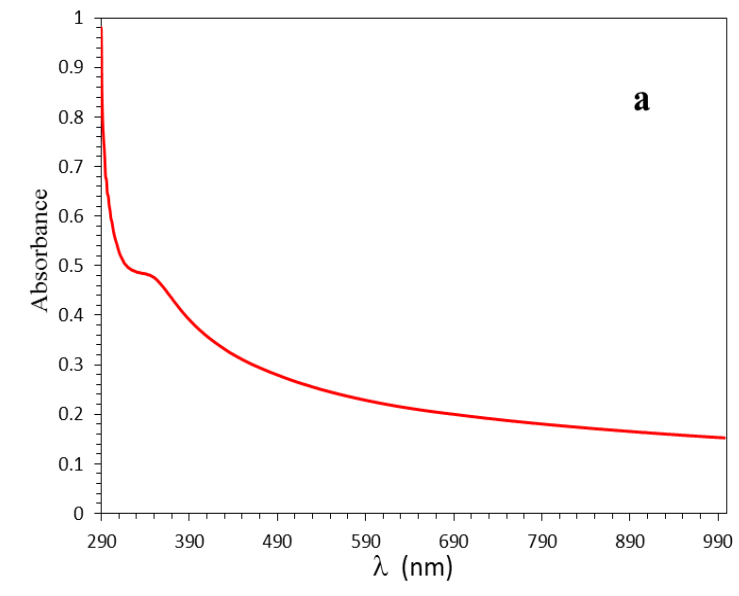

measuring transmittance (T), absorbance (A) and the energy band gap as shown in Fig. (1a, b) and Fig. 2. The transmittance of indium oxide thin films is measured in the wavelength region $300-1100 \mathrm{~nm}$ by using UV-Vis spectrophotometer. Absorption coefficient $(\alpha)$ can be used to estimate the band gap energy of $\mathrm{In}_{2} \mathrm{O}_{3}$ thin films. The relation between absorption coefficient $(\alpha)$ and incident photon energy (hv) can by represented by the tauc equation [7]:

$\alpha=\mathrm{A}\left(\mathrm{h} v-\mathrm{E}_{\mathrm{g}}\right)^{\mathrm{n}} / \mathrm{h} v$

Fig (1 a, b) shows high transmission at long wavelengths and decreasing transmission at short wavelengths for $\mathrm{In}_{2} \mathrm{O}_{3}$ thin films after heat treatment for $1 \mathrm{~h}$ at temperature $400{ }^{\circ} \mathrm{C}$.

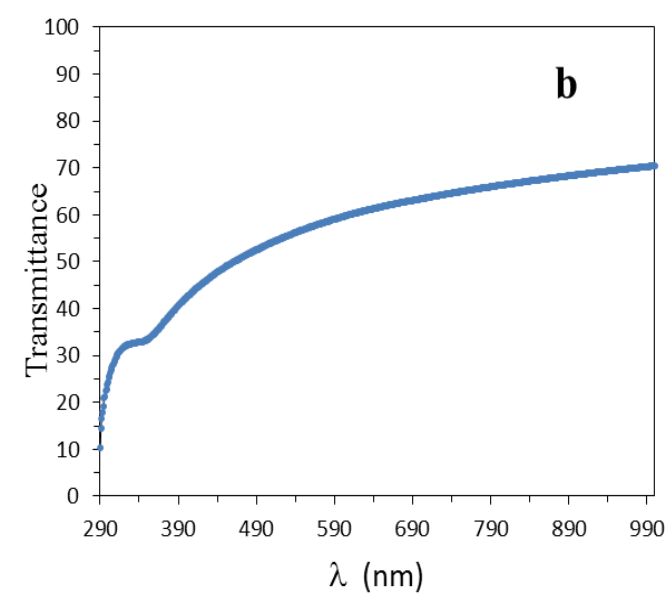

Fig. 1: a) Absorbance and b) Transmittance spectra of $\mathrm{In}_{2} \mathrm{O}_{3}$ thin films at heat treatment of Indium thin film at $400{ }^{\circ} \mathrm{C}$ for $1 \mathrm{~h}$.

Besides, the energy gap (Eg) for $\mathrm{In}_{2} \mathrm{O}_{3}$ is about $2.7 \mathrm{eV}$ as shown in Fig. 2. These observations clearly indicate that direct energy gap (Eg) at about $2.7 \mathrm{eV}$ is of intrinsic nature. This is in accordance with investigations by photoelectron spectroscopy locating the fundamental band gap between 2.7 and $2.9 \mathrm{eV}$ and improving effective high electron-hole recombination rate. 


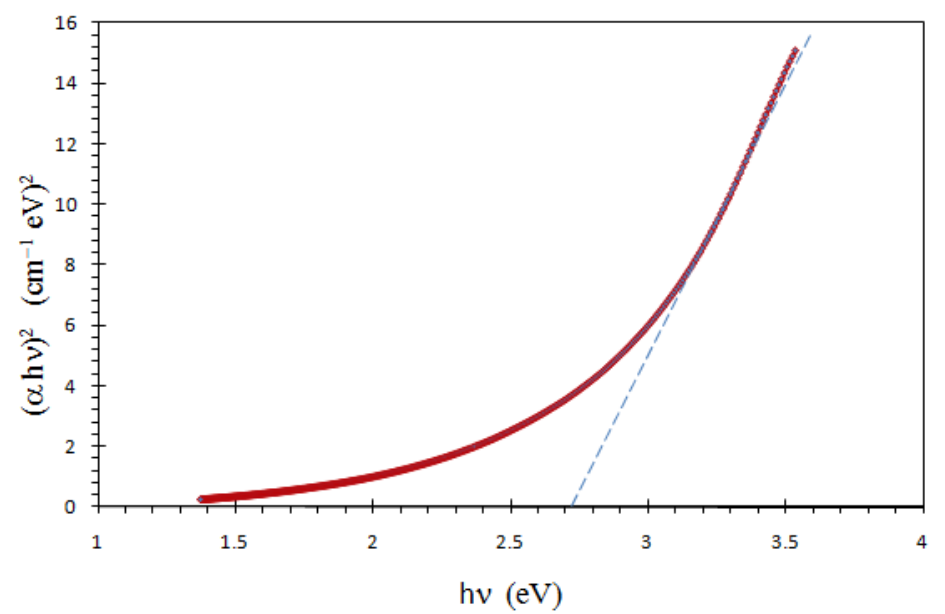

Fig. 2: Plot of $(\alpha h v)^{2}$ versus (hv) curve of $\mathrm{In}_{2} \mathrm{O}_{3}$ thin films get from oxidation of In metallic at $400{ }^{\circ} \mathrm{C}$.

\section{Structural characterization}

Fig. 3 shows the diffraction pattern of $\mathrm{In}_{2} \mathrm{O}_{3}$ array thin films at heat treatment of Indium, The heat treatment of Indium at $\mathrm{T}=400^{\circ} \mathrm{C}$ shows three diffraction peaks of $\operatorname{In}_{2} \mathrm{O}_{3}$ thin film at at $2 \theta=30.7^{\circ}, 35.1^{\circ}$ and $37.8^{\circ}$ which are assigned to the (222), (400) and (411) respectively according to (ASTM) [8] which improved crystalline phases of the $\mathrm{In}_{2} \mathrm{O}_{3}$ with grain size about $17.39 \mathrm{~nm}$ that determined by Scherrer formula [9]:

$D=\frac{K \lambda}{\beta_{2 \theta} \cos \theta}$

where $K$ is a dimensionless shape factor

$\lambda$ is the $X$-ray wavelength.

$\beta$ is the line broadening at half the maximum intensity (FWHM).

$\theta$ is the Bragg angle (in degrees).

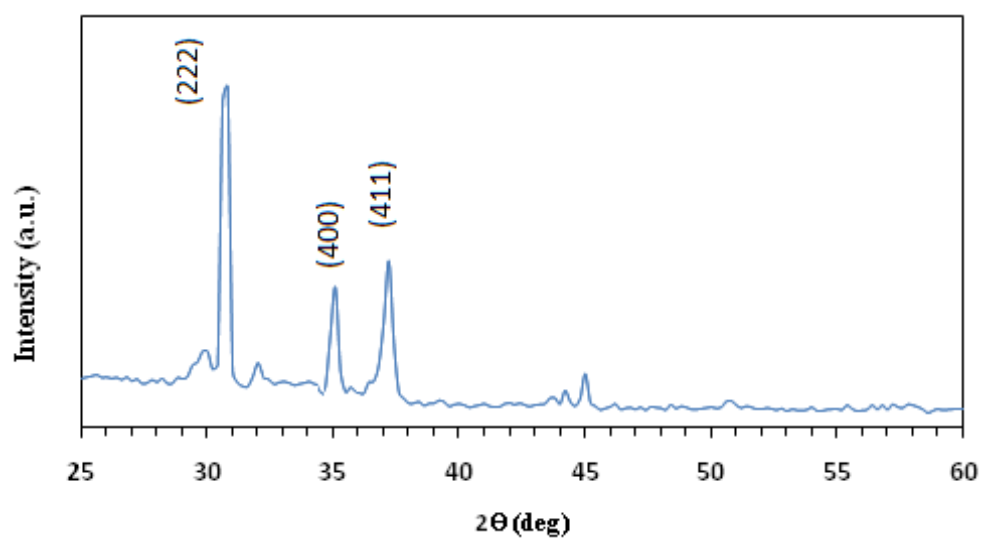

Fig. 3: X-Ray diffraction of $\operatorname{In}_{2} \mathrm{O}_{3}$ thin films after heat treatment of the thin films at $T=400{ }^{\circ} \mathrm{C}$.

Since, the intensities of array thin films the peaks increase at high temperature of the heat treatment of the thin films at $\mathrm{T}=400^{\circ} \mathrm{C}$ for $1 \mathrm{~h}$.

In Fig. 4 (a, b, c, d), SEM analysis of $\mathrm{In}_{2} \mathrm{O}_{3}$ thin films show array of square shaped morphology of the sample with homogeneous distributions over signification surface area of continuous phase. 

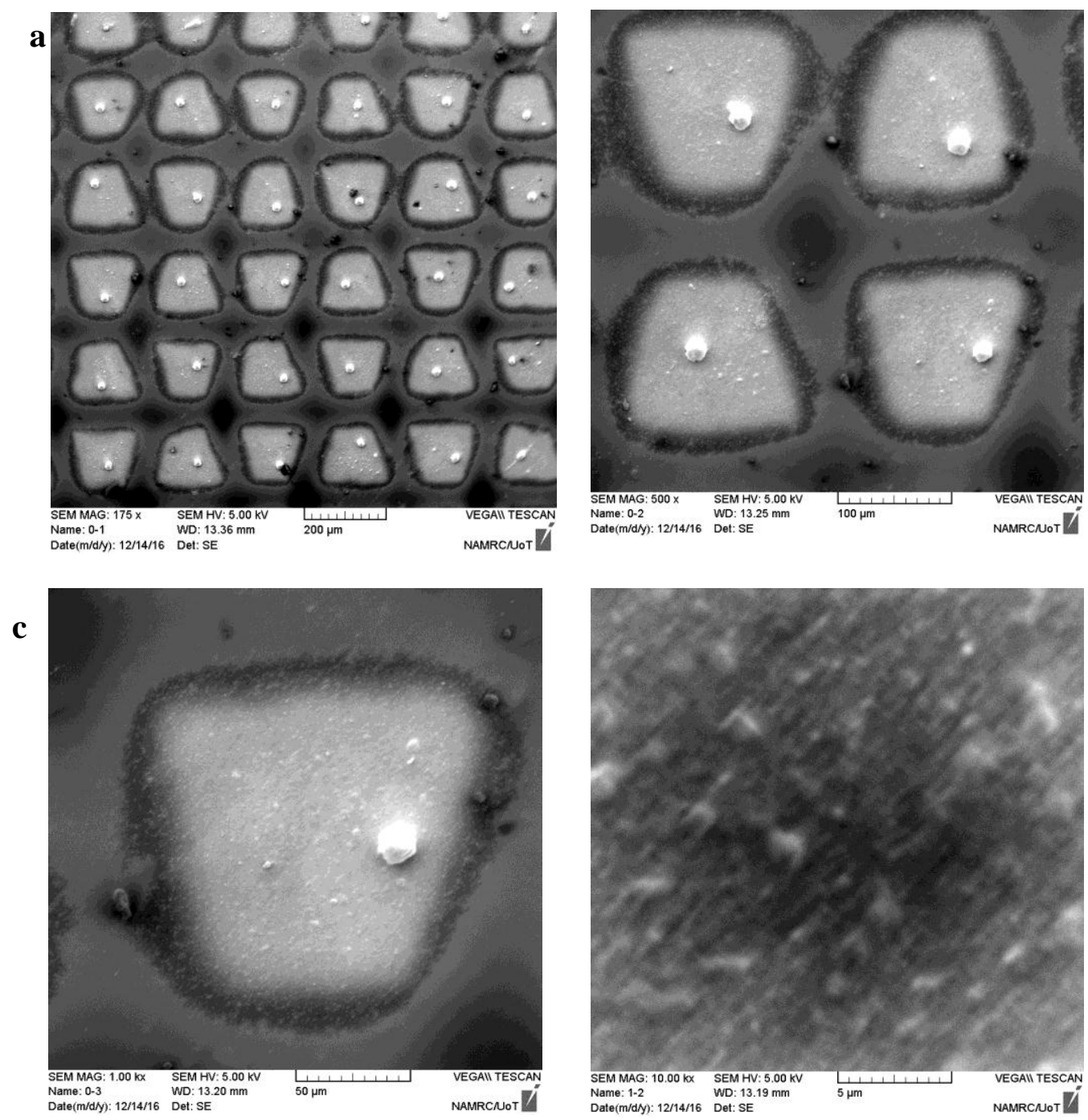

Fig. 4: $\mathrm{SEM}$ analysis of $\mathrm{In}_{2} \mathrm{O}_{3}$ thin films array after heat treatment at $\mathrm{T}=400^{\circ} \mathrm{C}$ at different magnification a) $200 \mu \mathrm{m}, \mathrm{b}) 100 \mu \mathrm{m}, \mathrm{c}) 50 \mu \mathrm{m}$ and d) $5 \mu \mathrm{m}$.

\section{Antibacterial activity of $\operatorname{In}_{2} \mathrm{O}_{3}$ thin films}

Antibacterial activity of $\operatorname{In}_{2} \mathrm{O}_{3}$ thin films against a Gram negative bacterium Escherichia coli (E.coli) was investigated by inhibition zone of bacteria as shown in Fig. $(5 \mathrm{a}, \mathrm{b}) . \mathrm{In}_{2} \mathrm{O}_{3}$ samples thin films after incubating at $37{ }^{\circ} \mathrm{C}$ for overnight demonstrate that films could inhibit the bacterial growth and there is no presence of bacteria on top and bottom of films. Besides, under the bottom of films there is zone of inhibition is found for gram negative bacteria as shown in Table 2 . Since, it is reported that $\operatorname{In}_{2} \mathrm{O}_{3}$ have strong antimicrobial effect against gram negative bacteria. The results demonstrate that $\mathrm{In}_{2} \mathrm{O}_{3}$ make a damages the structure of bacterial cell membranes and controls the activity of some membranous enzymes which kills the Escherichia coli and can be useful in the treatment of infectious diseases. 


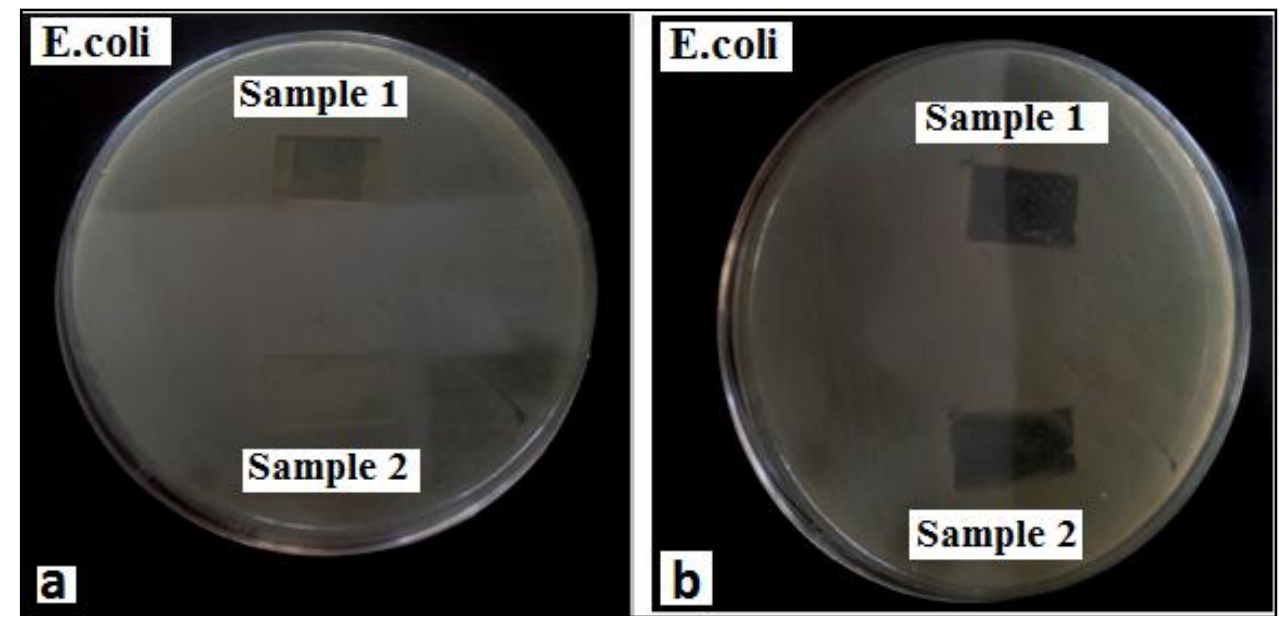

Fig. 5: Photography of inhibition zone of bacteria under $\mathrm{In}_{2} \mathrm{O}_{3}$ thin films against a Escherichia coli (E.coli) a) when the bottom of $\mathrm{In}_{2} \mathrm{O}_{3}$ thin films is still on the gel and b) under the bottom of $\mathrm{In}_{2} \mathrm{O}_{3}$ thin films when is rose from gel.

Table 2: Inhibition Zones diameters in (cm) of $\mathrm{In}_{2} \mathrm{O}_{3}$ thin films against E.coli bacteria.

\begin{tabular}{|c|c|}
\hline $\mathrm{In}_{2} \mathrm{O}_{3}$ Sample & Zones diameters in $(\mathbf{c m})$ \\
\hline Sample 1 & 3.1 \\
\hline Sample 2 & 3.5 \\
\hline
\end{tabular}

\section{Conclusions}

In conclusion, we have prepared array $\mathrm{In}_{2} \mathrm{O}_{3}$ thin films using thermal evaporation method at $400^{\circ} \mathrm{C}$ for $1 \mathrm{~h}$. The energy gap calculated from UVVis analysis improve that prepared array $\operatorname{In}_{2} \mathrm{O}_{3}$ thin films reveal band gap at about $2.7 \mathrm{eV}$. XRD analysis confirms crystalline phases of the $\mathrm{In}_{2} \mathrm{O}_{3}$ with grain size about $17.39 \mathrm{~nm}$ and SEM images improved the smaller size nanosize particles forming in square array structure of $\operatorname{In}_{2} \mathrm{O}_{3}$ films and features of thin films depend strongly on deposition method and parameter of oxidation. The antibacterial activities of $\operatorname{In}_{2} \mathrm{O}_{3}$ thin films confirm that films could inhibit the bacterial growth and there is no presence of bacteria on top and bottom of films and reveal the reactive oxygen species generated by thermal oxidation.

\section{References}

[1] R. Santhi, C. Shanthi, M. Sathya, K. Pushpanathan, Journal of Chemical and Pharmaceutical Research, 8, 9 (2016) 249-259.
[2] Y. Zhang, J.Q. Zhang, M.Y. Nie, K. Sun, J.Q. Li, C.H. Yu, J. Nano Part. Res., 17 (2015) 1-11.

[3] R. Zhang, X Lu, L. Huang, Z. Ke, Y. Li, J. Mater Sci. Mater Electron, 28 (2017) 8255-8265.

[4] Z. Li, P. Zhang, L. Jin., X. Li, Journal of Hazardous Materials, 260, 15 (2013) 40-46.

[5] S. Guo, X. Zhang, Z. Hao, G. Gao, G. Li , L. Liu, RSC Adv., 59, 4 (2014) 31353-31361.

[6] S. Shatha Batros Jamil, A. Areej Hateef, K. Habiba Atty, Phys. Sci. Res. Int., 3, 2 (2015) 18-25.

[7] J. Tauc, R. Grigorovici, A. Vancu, Phys. Status Solidi, 15 (1966) 627-637.

[8] S.W. Cao, X. F. Liu, Y. P. Yuan, Z. Y. Zhang, Y. S. Liao, J. Fang, S.C.J. Loo, T. C. Sum, C. Xue, Appl. Catal. B. 147 (2014) 940-946.

[9] M. Birkholz, P. F. Fewster, C. Genzel, WILEY-VCH Verlag $\mathrm{GmbH}$ \& Co., (2006). 